\title{
Література
}

1. Закон України «Про вищу освіту» [Електронний ресурс] Режим доступу: http://zakon2.rada.gov.ua/laws/show/1556-18. 2. Личностная и профессиональная рефлексия: психологический практикум / сост. Г. С. Пьянкова; Краснояр. гос. пед. ун-т им. В. П. Астафьева. - Красноярск, 2012. - 125 с. 3. Марусинець М. М. Професійна рефлексія майбутнього вчителя початкових класів: теорія i практика формування : [монографія] / М. М. Марусинець. - Умань: ПП Жовтий О. О., 2012. - 420 с. 4. Мирошник О. Г. Педагогічна рефлексія як чинник вияву творчого потенціалу особистості вчителя / О. Г. Мирошник // Естетика і етика педагогічної дії: [збірник наукових праць]. Київ - Полтава : Інститут педагогічної освіти і освіти дорослих НАПН та ПНПУ імені В. Г. Короленка. - 2011. - Вип. 2 - С. 47-57. 5. Мишина Ю. Д. Психолого-педагогические условия развития ответственности у студентов педагогических вузов : дисс. ... канд. пед. наук : 13.00.08 «Теория и методика профессионального образования»/ Мишина Юлия Дмитриевна; Новосибирский государственный педагогический университет. - Томск, 2002. - 261 с. 6. Педагогический энциклопедический словарь / гл. ред. Б. М. Бим-Бад; ред. кол. М. М. Безруких, В. А. Болотов, Л. С. Глебова, Е. Л. Гончарова, Н. Н. Малофеев, Е. Г. Осиповский, А. В. Петровский. - Москва : Большая Российская энциклопедия, 2002. 528 с. 7. Про особливості формування навчальних планів на 2015/2016 навчальний рік. Міністерство освіти і науки України. Наказ № 47 від 26 січня 2015 року [Електронний pecypc]. - Режим доступу: http://zakon3.rada.gov.ua /laws/show/z 0132-15. 8. Русакова О. В. Формирование умений и навыков саморегуляции на основе рефлексии у младших подростков в процессе обучения : дисс. ... канд. пед. наук : 13.00.01 «Общая педагогика, история педагогики и образования» / Русакова Ольга Владимировна ; ГОУ ВПО «Вятский государственный гуманитарный университет». - Киров, 2009. - 209 с.

УДК 378.147

Олександр Прокопченко

\section{АНАЛІЗ МОЖЛИВОСТЕЙ ВИКОРИСТАННЯ ІНТЕРАКТИВНИХ ПРОГРАМНИХ ЗАСОБІВ КОМП'ЮТЕРНОЇ МАТЕМАТИКИ В НАВЧАЛЬНОМУ ПРОЦЕСІ ПІДГОТОВКИ ФАХІВЦІВ-ФАРМАЦЕВТІВ}

Прокопченко О. С. Аналіз можливостей використання інтерактивних програмних засобів комп'ютерної математики в навчальному процесі підготовки фахівців-фармацевтів.

У статті розглянуто можливості впровадження інтерактивних програмних засобів комп'ютерної математики в навчальний процес підготовки фахівців-фармацевтів. На прикладі курсу «Основи вищої математики та математичної статистики» (Запорізький державний медичний університет, I курс фармацевтичного факультету) надано методичні рекомендації щодо ефективного та оптимального використання сучасних інноваційних та когнітивних технологій у навчальному процесі.

Ключові слова: комп’ютерна математика, програмні засоби, інтерактивні методи, інноваційні освітні технології, когнітивні методи навчання.

Прокопченко A. Е. Анализ возможностей использования интерактивных программных средств компьютерной математики в учебном процессе при подготовке специалистов-фармацевтов.

В статье рассмотрены возможности внедрения интерактивных программных средств 
компьютерной математики в учебный процесс подготовки специалистов-фармацевтов. На примере курса «Основы высшей математики и математической статистики» (Запорожский государственный медицинский университет, I курс фармацевтического факультета) представлены методические рекомендации по эффективному и оптимальному использованию современных инновационных и когнитивных технологий в учебном процессе.

Ключевые слова: компьютерная математика, программные средства, интерактивные методы, инновационные образовательные технологии, когнитивные методы обучения.

Prokopchenko O. E. The analysis of the possibilities of using interactive mathematical tools in teaching mathematics for the training of pharmacists.

The article discusses the possibility of introducing interactive software computer mathematics in the educational process of specialists majoring in pharmacist. The paper presents guidelines for effective and optimal use of modern innovative and cognitive technologies in educational process. The article describes an example («Foundations of Mathematics and Mathematical Statistics») for the use of Wolfram Mathematica technology in the educational process.

Key words: computer mathematics, interactive methods, innovative educational technologies, cognitive methods of teaching.

Візуальне й інтерактивне представлення інформації в процесі навчання залишається актуальною проблемою, що вимагає застосування новітніх освітніх технологій. Основою упровадження інноваційних, когнітивних навчальних технологій є створення умов для оптимального й ефективного сприйняття інформації $[1 ; 2 ; 3]$.

Навчальна дисципліна «Вища математика та основи математичної статистики» $є$ складовою частиною навчального плану на першому курсі медичного університету (фармацевтичний факультет) i грунтується на суто узагальненій та формалізованій інформації. Як наслідок, навчальний матеріал є ускладненим для сприйняття і засвоєння студентами. Проблемним та актуальним залишається мотивоване вивчення дисципліни.

Використання комп'ютерних математичних засобів візуалізації та моделювання у процесі вивчення основ математики дозволяє частково розв'язати вказані проблеми. Загальні інтерактивні методи і прийоми сприяють поданню навчальної інформації в образно-уявному вигляді та підвищенню ефективності навчального процесу загалом.

Метою публікації є аналіз можливостей використання програмних засобів комп’ютерної математики на прикладі Wolfram Mathematica в навчальному процесі у процесі підготовки фахівців-фармацевтів.

Вивчення основ вищої математики є проблемним і побудоване на розв'язанні проблем математичного характеру. Як відомо, візуалізація проблеми сприяє іiі розумінню та мотивованому сприйняттю як на рівні стадії формулювання задачі, так і подальшого аналізу отриманих результатів. Як приклад розв'язання навчально-методичних проблем автором були обрані програмні засоби комп'ютерної математики Wolfram Mathematica. Вибір зумовлений універсальністю й ефективністю цього програмного пакету. Де-факто, Wolfram Mathematica становить стандарт як для наукових, так і навчальних закладів та установ. Певною мірою Wolfram Mathematica є методичним засобом та інструментом викладача; містить структурований навчальний матеріал 3 математики, адаптований для навчальних закладів різного рівня і дозволяє оптимально розв'язувати розрахункові задачі, в тому числі, 
за допомогою онлайн-версії Wolfram Mathematica та аналогічного програмного засобу www.mathics.org.

У цілому система комп'ютерної математики від компанії Wolfram позиціонується виробником як універсальний математичний засіб або обчислювальне хмарне середовище із відповідною мовою програмування (Wolfram Natural Language Understanding System), системою моделювання (SystemModeler), підтримкою хмарних технологій (Wolfram Cloud), системою розгортання рішень для наукових досліджень (Wolfram Universal Deployment System та Wolfram Discovery Platform). Окрім того, Mathematica містить формат обчислювальних документів, що зберігає інтерактивність i динамічність. Останнє $\epsilon$ актуальним для розв’язання навчально-методичних проблем.

Особливу увагу привертає саме можливість публікації інтерактивних навчальних документів в форматі cdf (computable document format). Формат cdf становить контейнер знань і комунікаційний канал. Цей тип документа $є$ технічно універсальним, стандартним та оптимальним i може бути застосований в автономному режимі та режимі он-лайн. Пропонований до впровадження формат містить інформацію як у текстово-формульному, так і візуально-інтерактивному вигляді і має таку структуру та дидактичні елементи: стислий текстовий огляд навчальної проблеми й основні визначення, в тому числі формульні; інтерактивні ілюстрації, що замінюють класичний ілюстративний матеріал підручників; типові розрахункові математичні задачі 3 параметрами. На відміну від класичного представлення задач та їх розв'язків, документ у форматі cdf дозволяє представити задачу 3 параметрами у шаблонному вигляді. Змінюючи параметри математичних завдань, ми можемо отримати безліч умов і відповідних розв'язків. Студенти отримують можливість створювати завдання та аналізувати їх розв'язок,- аудиторні завдання набувають ознак індивідуальних і служать основою для самостійної індивідуальної роботи студентів.

Отже, формат інтерактивного подання інформації є дидактичною моделлю, яка дозволяє організувати аудиторні та позааудиторні заняття і ставить за мету ефективну й оптимальну трансляцію навчального матеріалу. Скорочення навчального матеріалу відбувається за рахунок оптимізації, структуризації та візуалізації навчальної інформації. Змістовність та обсяг при цьому не втрачаються. Технологія «Wolfram computable document format» розглядається автором також в ролі методичного інструментарію викладача, який дозволяє подавати навчальну інформацію в найбільш привабливому текстово-візуальному та інтерактивному вигляді, і надає змогу поширювати навчальні матеріали засобами інтернетмережі. Додатково документ cdf поєднує в собі функції і можливості навчальних презентацій. Але, на відміну від останніх, може містити більш розгорнуті елементи розрахункової математики. Безпосереднє використання розрахункової математики в текстовому документі є доцільним для розв'язку математичних задач з параметрами.

На першому етапі упровадження засобів комп'ютерної математики оптимальним $\epsilon$ використання окремих демонстрацій або моделей в ролі ілюстративного навчального матеріалу. Ми отримуємо можливість продемонструвати динаміку змін. Наприклад, зміна аргументу функції та інтерактивна рухома дотична на інтервалі графіка функції наочно здатні підвести до розуміння поняття похідної. У цілому, можуть бути застосовані демонстрації під час розгляду найбільш проблемних навчальних питань: геометричний зміст похідної, швидкість зростання (спадання) функції, точки екстремуму, інтегральна сума й інші. Отже, більшість проблем математичного аналізу (перший модуль навчальної дисципліни) та основ математичної статистики (другий модуль) можуть бути проілюстровані за допомогою демонстрацій із навчальної бази знань Wolfram Mathematica 
(demonstrations.wolfram.com) [4]. Окремі Інтернет-базовані різнорівневі і класифіковані за тематикою демонстрації були частково адаптованими нами до потреб візуалізації навчального процесу на рівні лекційного забезпечення та на рівні проведення аудиторних занять й організації самостійної роботи студентів.

Методично привабливим аспектом застосування інтерактивних демонстрацій $\epsilon$ альтернативність, - одна і та ж навчальна проблема може бути проілюстрована різними демонстраціями із бази знань. Окрім того, в подальшому привабливим може стати вивчення й аналіз програмного коду, який є відкритим і забезпечує інтерактивність демонстрацій.

Другий етап упровадження має супроводжуватись розрахунковими прикладами (завданнями) і має пряме відношення до спрощення й оптимізації процесу розв'язування прикладних задач 3 математики. Wolfram Mathematica має також опцію відтворення покрокового розв'язку, що стане в пригоді під час самостійної роботи студента. Опція реалізована в проекті WolframAlpha і є доступною в онлайн-версії та мобільних пристроях. На третьому етапі поєднуються: трансляція та структуризація; спрощення й оптимізація; візуалізація та розпізнавання проблем.

Запропонована технологія $€$ інноваційною для освіти та має відношення до когнітивних методів навчання; у перспективі $\epsilon$ актуальною як інструмент наукового дослідження. Упровадження в навчальний процес математичних демонстрацій-моделей i формування на їх основі інтерактивних навчальних матеріалів є оптимальним з точки зору спрощення, структуризації, стандартизації, візуалізації навчального матеріалу. Запропонована методика використання програмних засобів комп'ютерної математики в навчальному процесі відповідає сучасній концепції науки нового типу - A New Kind of Science [5].

\section{Література}

1. Лалак Н. В. Інтерактивна модель навчання студентів: проблеми та перспективи / Н. В. Лалак / Науковий вісник Ужгородського національного університету. - 2011. - № 20. С. 69-70. 2. Пометун О. І. Сучасний урок. Інтерактивні технології навчання : [наук.-метод. посібн.] / О.І.Пометун, Л.В.Пироженко ; за ред. О.І.Пометун. - Київ : Видавництво А.С.К., 2004. - 192 с. 3. Прокопченко О. С. Аксіоми дистанційної, Інтернет базованої навчальної системи та прояв нових тенденцій у розвитку українського освітнього простору / О. Є. Прокопченко // Актуальні питання фармацевтичної та медичної науки та практики : [зб. наук. статей] / за ред. Ю. М. Колесника [та ін.]. - Запоріжжя, 2006. - Вип. 16. - С. 45-51. 4. Prokopchenko O. Sampling Statistics and Statistical Estimation [Електронний ресурс]/ O. Prokopchenko. - Режим доступу: http:// demonstrations.wolfram.com/SamplingStatistics And StatisticalEstimation. 5. Wolfram S. A New Kind of Science / S. Wolfram. - Wolfram Media, Inc., $2002-1192 \mathrm{p}$.

УДК 808.5:811.162.1

Оксана Ранюк

\section{ФОРМУВАННЯ РИТОРИЧНОЇ КОМПЕТЕНЦЇ̈ СТУДЕНТІВ-ФІЛОЛОГІВ ПІД ЧАС ВИВЧЕННЯ ПОЛЬСЬКОЇ МОВИ}

Ранюк О. П. Формування риторичної компетенції студентів-філологів під час вивчення польської мови.

У статті теоретично обгрунтовано поняття «компетенції» та «риторичної компетенції». Зазначено, як можна використовувати риторичний елемент під час вивчення 